\title{
"Prospective Business Startups": Characteristics of Managers of State-owned Enterprises from the Perspective of Human Capital
}

\author{
Xiaoming Qiao \\ Journal Editorial Department, Yunnan Normal University, Kunming, Yunnan, 650092
}

Keywords: State-Owned Enterprises, Managers, Human Capital, Prospective Business Startups

\begin{abstract}
This paper argues that state-owned enterprise managers are a kind of special human capital between the free market and the planned economy, and belong to the category of "quasi-entrepreneurs". This is because, on the one hand, they have initially taken on some of the characteristics of free market entrepreneurs; on the other hand, they still carry the behavioral characteristics of SOE managers in the era of planned economy.
\end{abstract}

\section{Introduction}

At present, our country is still at a critical period of gradual transformation from a planned economy to a market economy. So, as the backbone of the national economy, state-owned enterprises, their managers compared with the era of the planned economy, what happened? What are the similarities and differences compared with the entrepreneurs under the free market in the western market? This paper attempts to draw on the existing entrepreneurial theory, gives a general theoretical framework, and use this framework to analyze the current state-owned enterprise managers behavior characteristics.

\section{Brief Commentary on the Theory of Representative Entrepreneurs}

Knight's theory. Knight conducted a pioneering research on the existence of enterprises based on the uncertainty and entrepreneurship. He pointed out that in the uncertain conditions, the implementation of a specific economic activity has become a secondary part of life; the first issue or function is to decide what to do and how to do it. Among them, the "first function" refers to the entrepreneur's function. Because uncertainty is an objective reality, entrepreneurs have to bear the uncertainty. To Knight, a business is a special device by which a confident or brave risk taker takes a risk and ensures that indecisive or cowardly individuals receive a fixed income. Here he views the worker as a hesitant or coward, while viewing the entrepreneur as an authority who can provide workers with protection and welfare. The defects of Knight's theory are: firstly, it does not separate the "primary function" from the risk-bearing uninsurance; secondly, it fails to clearly distinguish the capitalist from the entrepreneur. Knight argues that since the "primary" Function "is to take risks, so he is naturally a capitalist.

Schumpeter's theory. Unlike Knight's theory, Schumpeter argues that uncertainty is borne by capitalists rather than entrepreneurs. Although entrepreneurs can also assume uncertainty, they must wait until he becomes a capitalist. The core of Schumpeter's theory is "innovation," and he believes that entrepreneurs are people who combine elements of production to create new production functions. Entrepreneurs are inevitably innovators. It is through innovation that they have broken the original balance and realized the profit of innovation, thus reflecting their own value. However, Schumpeter's theory obviously has some shortcomings. First of all, the preconditions for its theory to exist - personal rationality and complete information do not exist in reality. Second, Schumpeter places entrepreneurs in a position that is beyond the market and the organization. In fact, entrepreneurs can only fulfill their innovative functions only if they are attached to a certain organization. Finally, in his theory, the risks and benefits borne by entrepreneurs are not symmetrical. They enjoy the benefits of innovation but not the operational risks, which are not possible in real life. 
Zhang Wei Ying theory. Zhang Weiying set up a two-dimensional model of business capability and personal wealth in his doctoral dissertation The Entrepreneurial Contract Theory of Enterprise, and constructed a matrix combination of business ability and personal wealth. Different combinations established the enterprise the classification of family, managers, capitalists, and workers. Those who have no wealth or entrepreneurial power choose the role of workers; those who have wealth and entrepreneurial power choose the entrepreneurial role; those who have no wealth but entrepreneurial power choose managers; finally, those who have the property but do not have the entrepreneurial ability choose the capitalist role. This model undoubtedly has some enlightenment significance, but there are also some questions that are worth discussing. First, it is a model of transcendental determinism. In his opinion, both managerial ability and personal wealth seem to be static invariants that are innate. In fact, the day after tomorrow's hard work and hard work may be more important to the growth of an entrepreneur. Second, his model rejects the role of social capital such as social status, relationships, and credit. Finally, there is an implicit market for human capital in his model. In this market, the only signal used to screen entrepreneurship is the amount of wealth held by auctioneers. In fact, selecting an entrepreneur depends more on his past performance.

\section{Entrepreneurs: A General Sense of the Analytical Framework}

The definition of entrepreneurs. What is an entrepreneur? Due to the different times and perspectives, the definitions given may be very different. Entrepreneurs are first and foremost a category of history, and they change with the development of the times. Entrepreneurs are also a category of society. Their study involves disciplines in different fields such as economics, management science, psychology, sociology and many more. Therefore, to give an all-encompassing definition apparently contradicts the objective reality. In this way, only a descriptive definition can be given, which is called a descriptive definition: one is that the understanding reached by entrepreneurs is not completely unanimous now; the second is that there are still many gaps left waiting to dig, fill. Based on this understanding, this article tries to give a descriptive definition: "an entrepreneur is a type of enterprise that can creatively deal with various uncertain conditions and maximize the profits of an enterprise under the established institutional arrangements. Dedicated human capital."

As an entrepreneur, he should have the following capabilities: First, innovation. Innovation is the essential attribute that entrepreneurs differ from other general managers. Can not be innovative, simply not eligible to be called entrepreneurs. Innovation is reflected in two aspects: identifying opportunities and innovating processes. Identify opportunities is to find opportunities in the market imbalance; innovation process is the opportunity to convert timely profits into the process. Identification of opportunities is the premise and foundation, and innovation is the means to obtain profits for the purpose. Second, the ability to deal with uncertainty. Uncertainty for an entrepreneur is an objective reality, can only choose to face, can not choose to evade. The ability to deal with uncertainty includes the ability to identify and afford. Recognition ability refers to the ability to capture signals that have been related to one another from asymmetric information. To assume or absurd ability is to amplify and rapidly utilize signals that are beneficial to oneself based on the acquired information, which will be detrimental to oneself Signal attenuation and its negative impact on the ability to minimize. Third, organizational leadership. To achieve the goal of innovation, entrepreneurs must adhere to a certain organization and motivate their followers with the realization of organizational goals so that they feel that follow-up is valuable, hopeful and rewarding. Fourth, increasing marginal returns ability. As a type of dedicated human capital, entrepreneurs possess the know-how and skills that have been developed through years of learning and practice. It is the existence of these specialized knowledge and skills that determines that entrepreneurs are not human capital in the ordinary sense of the word but rather human capital with marginal returns increasing.

The role and role of entrepreneurs. The investigation of the functions and roles of entrepreneurs should be conducted on two levels. First, within the organization. As a dedicated human capital, 
entrepreneurs must conclude a contract with other non-human capital within the organization. Organizations are the carriers of entrepreneurship innovation. Only when they participate their own human capital as an element in the arrangement of organizational contracts, can they occupy a superior position in the organization, exert their entrepreneurial abilities and realize their value of life. The functions of an entrepreneur and a capitalist are fundamentally different. Capitalists provide capital, and entrepreneurs do business, the relationship between the two is not so much a relationship between employment and employment, but rather a cooperative relationship. Moreover, for an organization with adequate capital conditions, entrepreneurs may appear to be more important and scarcer than capitalists. As the owner of dedicated human capital, entrepreneurs have natural capital property features. On the one hand, they can create excess profits. The existence of this creative power has created the foundation for entrepreneurs to settle down for life. Likewise, it is the existence of this ability that explains why the fate of a business success or failure is so closely linked with its entrepreneurs. Therefore, to say that entrepreneurs are the soul of an enterprise can not be overestimated. On the other hand, private entrepreneurial human capital is naturally attached to its owners and inseparable from its owners. This natural dependency determines that entrepreneurs can only inspire without slavery or fraud. Because entrepreneurs hold a lot of business information, the performance of enterprises depends largely on the enthusiasm of entrepreneurs to play. Second, in the market. The real market is often in an unbalanced state. It is this unbalanced existence that gives entrepreneurs the opportunity to implement an innovation process, thereby reducing the transaction costs in the market and ultimately generating excess profits. The excess profits generated by the innovation process also lead to the imitation of other market entrants, resulting in the excess profits tended to disappear and the market entered a higher level of imbalance. The new imbalance will prompt entrepreneurs to implement a new round of innovation so that the economy will continue to move forward.

The conditions of entrepreneurs. That is, what conditions have been possible to grow into entrepreneurs? This paper argues that the conditions for becoming an entrepreneur can be divided into two kinds of internal conditions and external conditions. The so-called internal conditions, is to have several entrepreneurial capabilities mentioned earlier. Entrepreneurial ability to obtain, is achieved in a dynamic investment process, and entrepreneurial innate qualities are just the basis for obtaining this ability. In addition to education and training, they are more apparent in innovative practice. The so-called external conditions, refers to entrepreneurs in the social network, family background and political status of the constraints. These conditions, collectively referred to as the entrepreneur's social capital. Compared with entrepreneurial human capital, entrepreneurial social capital is also important for the growth of an entrepreneur, and sometimes it may even outperform human capital, for example, under planned economic conditions. However, in general, human capital determines social capital, which in turn affects human capital. The combined effect of the two determines the conditions for the growth of an entrepreneur.

\section{4. "Prospective Entrepreneurs": The Characteristics of State-owned Enterprise Managers}

In the planned economy, the growth model of SOE managers is essentially a dominant model of political capital. In other words, although SOE managers have a certain amount of human capital, such human capital does not necessarily have the ability to increase marginal returns, and may not necessarily determine the fate of a manager. At that time, human capital had to retreat to secondary positions under the squeeze of political capital. The so-called political capital under the conditions of a planned economy mainly refers to the social capital, that is, the individual's resources occupied in the social structure, including social status, political appearance and similar family background, the membership of a certain group, The relationship between characters, and so on. The nature of political capital determines the behavioral characteristics of SOE managers in the era of planned economy: First, there is not enough motivation for innovation. Due to the softening of budgetary constraints and the imperfect incentive mechanism, managers simply do not have the motivation to innovate, but are content with fulfilling the tasks entrusted to them by superiors. "Not seeking meritorious service, but seeking no solution" is a portrayal of the true state of mind of most of them. 
Second, the responsibility is empty. That is, it is not necessary to assume the business risks. All the consequences are ultimately borne by the government. The risk of managers is, at best, some of the losses caused by job changes. Third, the target is diversified. Not to maximize corporate profits as the goal, there are other social goals and even political goals. Fourth, the management methods are not economical. They are reluctant to choose the mode of market competition and are willing to choose the way in which the government is involved in helping the competition. The means of management is not oriented at maximizing profits but at reflecting the will of the administration. The pursuit of the scale of the enterprise is not based on the fact that it is bigger and bigger, but on the political treatment derived from "official standard" and so on.

In the strictest sense, SOE managers in a planned economy are not real entrepreneurs at all. However, with the advent of social transition, many changes have taken place in this group. First, there is an increase in innovation. Management studies confirm that innovation is not, in many cases, a manager's spontaneous behavior and is not their Pareto optimal choice. They choose to innovate because of the external pressure they face. Again, this can be used to explain why SOE managers in transition have experienced more innovation. The pressure on SOE managers in the transition period mainly comes from the three markets of products, managers and capital. Among them, the product market, the greatest pressure, this is because the judge a business manager level, the most intuitive way is to look at the market share of enterprise products. With the deepening of the reform and opening up, state-owned enterprise managers have also started to face more talent competition from both domestic and overseas markets, and the trend toward a unified national and global allocation of human resources has become increasingly evident. The increasing sophistication of capital markets has also put pressure on SOE managers, as the level of corporate creditworthiness and funding capacity directly reflect the level and capacity of managers. Second, the ability to deal with uncertainty increases. As market competition aggravates, SOEs are faced with more and more uncertainties and risks. The ability to identify and mitigate risks has become a very important part of the manager's capacity structure. The uncertainty that stems from institutional changes makes them more and more experienced in this area. And, to a large extent, they have started to assume more of the risks they should bear. Third, business objectives tend to be unified. Although some social goals still have to be fulfilled by transitional SOE managers, they have come closer and closer to the goal of profit maximization in market-oriented reforms. Fourth, the role of political capital tends to weaken. Now, the evaluation of the performance of SOE managers has tended to adopt performance standards. The relationship between state-owned enterprise managers and higher-level authorities gradually became loose, and the allocation of human and financial resources, the excess control and decision-making power increased. The attributes of state-owned enterprise managers as a kind of special-purpose human capital in transition are gradually recognized, and the return of ownership corresponding to the value of their human capital gradually emerges.

\section{Definition of the Behavior Characteristics of SOE Managers in Transition Period}

Although the behavioral characteristics of state-owned managers in transition have undergone great changes compared with those in the planned economy, they are still significantly different from the free market entrepreneurs. So, how to define the characteristics of SOE managers in transition? This paper argues that SOE managers in transition still can not count as true entrepreneurs. They are just a transitional area between the planned economy and market freedom, which we call "quasi-entrepreneurs." On the one hand, they have started to possess some of the characteristics of free market entrepreneurs and began to reflect their human capital value; on the other hand, they are still subject to the constraints of social and political capital (especially the higher authorities), not the market Free entrepreneurs are largely bound by market competition. Together, these two dimensions determine the subtle and intriguing aspects of their current situation. Of course, things are turning toward a good direction. The government departments have begun to become more and more rational. The "mayor's economy" has also begun to give way to the "market economy," and the relationship between government and enterprises has also become harmonious. 
When all this is done, SOE managers will become "true entrepreneurs" and become real entrepreneurs and realize their life-changing goals.

\section{References}

[1] Zhang Weiying. Entrepreneurs - contract theory [M]. Shanghai: Shanghai Joint Publishing, 1995: 45.

[2] Zhou Qiren. Enterprises in the market: a special contract between human capital and non-human capital [J]. Biological Research, 1996 (6):55.

[3] Miao Wenqing. State-owned enterprises entrepreneurial incentive system changes [J]. Reform, 2006 (11):34. 